\title{
Perlindungan Mutasi Guru dengan Berlakunya Undang-undang No 23
} tahun 2014 Pemerintahan Daerah

\author{
Itok Dwi Kurniawan $^{1 \bowtie}$, Suwarma Al Muchtar ${ }^{2}$
}

Universitas Sebelas Maret

\section{Informasi Artikel \\ Hisrtory of Article \\ Received March 2019 \\ Accepted May 2019 \\ Pusblished July 2019}

\section{Keywords:}

Regional autonomy,

Protection, Regional

Government, Teacher

Mutations

\begin{abstract}
Indonesia is a country based on the rule of law, this is in accordance with the mandate of the constitution. Citizens, in this case especially teachers must get protection in order to be able to carry out their rights and obligations comfortably. After the enactment of Law Number 32 Year 2004 to Law Number 23 Year 2014, secondary education became a provincial affair so there were a lot of teacher mutations. To anticipate this, the government issued a Circular Letter of the Minister of Home Affairs Number 120/5935 / SJ dated October 16, 2015 concerning the Acceleration of the Implementation of Affairs Under Act Number 23 of 2014 concerning Regional Government. The aim of this research is to determine the protection of teacher mutations by the enactment of local government laws. Teachers' protection according to this study can be divided into two, namely preventive (cancellation of regulations / Perbup / Perwali) and repressive (lawsuit of the State Administrative Court). Legal protection for teachers can be done preventively and repressively. Preventively, it could be through the governor's authority as a representative of the government to overturn the decision and repressively, the teacher could submit a claim to the State Administrative Court to cancel the letter of its decision. The existence of this law is expected to improve the welfare of teachers throughout Indonesia.
\end{abstract}

\begin{abstract}
Abstrak
Negara Indonesia adalah negara yang berdasarkan pada aturan hukum, hal ini sesuai dengan amanah konstitusi. Warga negara, dalam hal ini khususnya guru harus mendapatkan perlindungan agar bisa menjalankan hak dan kewajibannya dengan nyaman. Setelah berlakunya UU Nomor 32 Tahun 2004 ke UU Nomor 23 Tahun 2014, pendidikan menengah menjadi urusan provinsi sehingga banyak sekali terjadi mutasi guru. Untuk mengantisipasi hal tersebut, pemerintah mengeluarkan Surat Edaran Menteri Dalam Negeri Nomor 120/5935/SJ tanggal 16 Oktober 2015 tentang Percepatan Pelaksanaan Pengalihan Urusan Berdasarkan Undang-Undang Nomor 23 Tahun 2014 tentang Pemerintahan Daerah. Tujuan peneitian ini adalah untuk mengetahui perlindungan mutasi guru dengan berlakunya undang-undang pemerintah daerah. Perlindungan bagi guru menurut penelitian ini dibedakan menjadi dua, yaitu preventif (pembatalan perda/perbup/perwali) dan represif (gugatan Pengadilan Tata Usaha Negara). Perlindungan hukum terhadap guru bisa dilakukan secara preventif dan represif. Secara preventif, bisa melalui kewenangan gubernur sebagai wakil pemerintah untuk membatalkan keputusan tersebut dan secara represif, guru bisa mengajukan tuntutan kepada pengadilan Tata Usaha Negara untuk membatalkan surat keputusan mutasinya. Dengan adanya undang-undang tersebut diharapkan dapat meningkatkan kesejahteraan para guru di seluruh Indonesia.
\end{abstract}




\section{PENDAHULUAN}

Salah satu perubahan UU Nomor 32 Tahun 2004 ke Undang-undang Nomor 23 Tahun 2014 tentang pemerintahan daerah adalah menyangkut sektor pendidikan. Sebagaimana dijelaskan dalam penjelasan UU Nomor 23 Tahun 2014, kewenanangan pemerintah kota/kabupaten memiliki urusan pemerintahan bidang pendidikan sampai tingkat dasar (SD dan SMP), sedangkan pemerintah provinsi memiliki kewenangan sampai tingkat SMA. Jika pendidikan menengah setingkat SMA/SMK diubah menjadi kewenangan pemerintah provinsi, akan terjadi perubahan anggaran dan personel bagi pendidik dan tenaga kependidikan di SMA/SMK yang ada di kota/kabupaten.

Perubahan tersebut sudah diberikan ramburambu oleh Surat Edaran Menteri Dalam Negeri Nomor 120/5935/SJ tanggal 16 Oktober 2015 tentang Percepatan Pelaksanaan Pengalihan Urusan Berdasarkan Undang-Undang Nomor 23 Tahun 2014 tentang Pemerintahan Daerah. Selain urusan pendidikan, Pasal 14 Undang-Undang Nomor 23 Tahun 2014 tentang Pemerintahan Daerah di Ayat (1) menyatakan Penyelenggaraan Urusan Pemerintahan bidang kehutanan, kelautan, serta energi dan sumber daya mineral dibagi antara Pemerintah Pusat dan Daerah provinsi, Ayat (2) menyatakan Urusan Pemerintahan bidang kehutanan sebagaimana dimaksud pada Ayat (1) yang berkaitan dengan pengelolaan taman hutan raya kabupaten/kota menjadi kewenangan Daerah kabupaten/kota. Ayat (3) menyatakan Urusan Pemerintahan bidang energi dan sumber daya mineral sebagaimana dimaksud pada Ayat (1) yang berkaitan dengan pengelolaan minyak dan gas bumi menjadi kewenangan Pemerintah Pusat, dan Ayat (4) menyatakan Urusan Pemerintahan bidang energi dan sumber daya mineral sebagaimana dimaksud pada Ayat (1) yang berkaitan dengan pemanfaatan langsung panas bumi dalam Daerah kabupaten/kota menjadi kewenangan Daerah kabupaten/kota.

Terhadap hal di atas, Surat Edaran Menteri Dalam Negeri Nomor 120/5935/SJ tanggal 16 Oktober 2015 tentang Percepatan Pelaksanaan Pengalihan Urusan Berdasarkan Undang-Undang Nomor 23 Tahun 2014 tentang Pemerintahan
Daerah dalam angka (1) menyatakan penyelesaian secara seksama inventarisasi personel, sarana dan prasarana, pendanaan, dan dokumen sebagai akibat pengalihan urusan konkuren paling lambat tanggal 31 Desember 2015. Untuk serah terima berita acara personel, sarana dan prasarana serta dokumen, paling lambat tanggal 2 Oktober 2016, sedangkan terkait serah terima berita acara pendanaan paling lambat tanggal 31 Desember 2016 dan angka (2) menyatakan tidak diperkenankan untuk melakukan mutasi/perpindahan personel yang beralih urusannya di internal provinsi dan kabupaten/kota, dan pengalihan batang milik daerah baik antar pengguna barang dan/atau jasa kuasa pengguna barang sebelum adanya penyerahan barang milik daerah.

Jika kita membaca SE Mendagri Nomor 120/5935/SJ tanggal 16 Oktober 2015 tentang Percepatan Pelaksanaan Pengalihan Urusan Berdasarkan Undang-Undang Nomor 23 Tahun 2014 tentang Pemerintahan Daerah, tidak boleh ada mutasi/perpindahan personel yang beralih urusannya di internal provinsi dan kabupaten/kota, dan pengalihan batang milik daerah baik antar pengguna barang dan/atau jasa kuasa pengguna barang sebelum adanya penyerahan barang milik daerah. Namun, yang menjadi persoalan adalah kalimat "beralih urusannya". Hal ini karena urusan pemerintah sebagaimana Pasal 9 UU Nomor 23 Tahun 2014 tentang Pemerintahan Daerah terdiri atas urusan pemerintahan absolut, urusan pemerintahan konkuren, dan urusan pemerintahan umum.

Jika tidak ada penjelasan SE Mendagri Nomor 120/5935/SJ tanggal 16 Oktober 2015 tentang Percepatan Pelaksanaan Pengalihan Urusan Berdasarkan Undang-Undang Nomor 23 Tahun 2014 tentang Pemerintahan Daerah, pemerintah daerah bisa saja menafsirkan urusan beralih itu urusan pemerintahan konkuren ke urusan pemerintahan absolut. Hal ini tidak diperbolehkan oleh SE Mendagri Nomor 120/5935/SJ tanggal 16 Oktober 2015 tentang Percepatan Pelaksanaan Pengalihan Urusan Berdasarkan Undang-Undang Nomor 23 Tahun 2014 tentang Pemerintahan Daerah karena mutasi/perpindahan tersebut mengakibatkan berpindahnya personel, sarana dan prasarana serta dokumen dari pemerintah daerah 
kota/kabupaten ke pemerintah pusat, baik di internal kabupaten/kota maupun provinsi.

Peralihan kewenangan di bidang pendidikan juga menimbulkan banyak masalah. Hal ini terjadi karena adanya penafsiran bahwa untuk menjamin terjaganya kualitas layanan urusan pemerintahan yang terjadi peralihan urusan sebagai akibat perubahan pembagian urusan berdasarkan UU Nomor 23 Tahun 2014 tentang Pemerintahan Daerah, tidak diperkenankan untuk melakukan mutasi/perpindahan personil. Sudah dijelaskan dalam UU Nomor 23 Tahun 2014 tentang Pemerintahan Daerah bahwa urusan pemerintahan di bidang pendidikan termasuk urusan konkuren yang berkaitan dengan urusan pemerintahan wajib. Sebagaimana diketahui, angka 1 SE Mendagri Nomor 120/5935/SJ tanggal 16 Oktober 2015 tentang Percepatan Pelaksanaan Pengalihan Urusan Berdasarkan Undang-Undang Nomor 23 Tahun 2014 tentang Pemerintahan Daerah menyebutkan "sebagai akibat pengalihan urusan konkuren". Urusan konkuren tersebut tentunya menjadi urusan pemerintah kota/kabupaten dan provinsi serta menjadi dasar pelaksanaan Otonomi Daerah. Jika kita mengartikan "beralih urusannya" itu sebagai beralihnya urusan konkuren, baik dari pemerintah kota/kabupaten ke pemerintah provinsi maupun sebaliknya, mutasi/perpindahan pendidik dan tenaga kependidikan tidak diperkenankan.

Namun, dalam pelaksanaannya, masih banyak terjadi mutasi/perpindahan pendidik dan tenaga kependidikan, Jika guru yang dahulunya kepala sekolah, kemudian dijadikan guru biasa sebelum tanggal 2 Oktober 2016, apakah hal itu diperbolehkan? Secara normatif sebagaimana dinyatakan dalam SE Mendagri Nomor 120/5935/SJ tanggal 16 Oktober 2015 tentang Percepatan Pelaksanaan Pengalihan Urusan Berdasarkan Undang-Undang Nomor 23 Tahun 2014 tentang Pemerintahan Daerah, hal tersebut tidak diperkenankan.

Jika pemerintah kota/kabupaten tersebut nekad melakukannya, apakah yang harus dilakukan oleh guru? Guru secara normatif, memang telah mendapatkan perlindungan, sebagaimana ketentuan Pasal 39 Undang-Undang Nomor 14 Tahun 2005 dalam Ayat (1) "Pemerintah, pemerintah daerah, masyarakat, organisasi profesi, dan/atau satuan pendidikan wajib memberikan perlindungan terhadap guru dalam pelaksanaan tugas". Rumusan undang-undang tersebut telah memberikan dan mewajibkan adanya perlindungan kepada guru dalam tugasnya. Adapun Ayat (2) menyatakan ruang lingkup perlindunginya yang meliputi "Perlindungan sebagaimana dimaksud pada Ayat (1) meliputi hukum, perlindungan profesi, serta perlindungan keselamatan dan kesehatan kerja"Ketentuan ini membedakan secara tegas tentang perbedaan antara perlindungan hukum, perlindungan profesi, perlindungan keselamatan kerja, dan perlindungan kesehatan kerja.

\section{METODE}

Metode penelitian ini berjeniskan metode penelitian hukum normatif dengan pendekatan doktrinal yang berlandaskan data sekunder. Data sekunder tersebut adalah Undang-Undang Nomor 23 Tahun 2014 tentang Pemerintahan Daerah, Undang-Undang Nomor 51 Tahun 2009 jo Undang-Undang Nomor 9 Tahun 2004 jo UndangUndang Nomor 5 Tahun 1986 tentang Pengadilan Tata Usaha Negara, Undang-Undang Nomor 20 Tahun 2003 tentang Sistem Pendidikan Nasional, SE Mendagri Nomor 120/5935/SJ tanggal 16 Oktober 2015 tentang Percepatan Pelaksanaan Pengalihan Urusan Berdasarkan Undang-Undang Nomor 23 Tahun 2014 tentang Pemerintahan Daerah. Analisis data yang digunakan adalaha analisis data kualitatif.

Penelitian ini bertujuan menganalisis perlindungan hukum bagi guru yang dimutasi setelah diberlakukannya Undang-Undang Nomor 23 Tahun 2014 tentang Pemerintahan Daerah dan menyebutkaan bentuk perlindungan hukum bagi guru apabila dia dimutasi setelah diberlakukannya Undang-Undang Nomor 23 Tahun 2014 tentang Pemerintahan Daerah.

\section{HASIL DAN PEMBAHASAN}

Negara Indonesia merupakan negara hukum sehingga memiliki kewajiban untuk memberikan perlindungan hukum kepada warga negaranya. Perlindungan hukum adalah memberikan pengayoman kepada hak asasi 
manusia yang dirugikan orang lain dan perlindungan tersebut diberikan kepada masyarakat agar mereka dapat menikmati semua hak-hak yang diberikan oleh hukum atau dengan kata lain perlindungan hukum adalah berbagai upaya hukum yang harus diberikan oleh aparat penegak hukum untuk memberikan rasa aman, baik secara pikiran maupun fisik dari gangguan dan berbagai ancaman dari pihak mana pun (Satjipto Rahardjo, 2001).

Pengertian lain perlindungan hukum adalah perlindungan akan harkat dan martabat, serta pengakuan terhadap hak-hak asasi manusia yang dimiliki oleh subyek hukum berdasarkan ketentuan hukum dari kesewenangan atau sebagai kumpulan peraturan atau kaidah yang akan dapat melindungi suatu hal dari hal lainnya. Berkaitan dengan konsumen, berarti hukum memberikan perlindungan terhadap hak-hak pelanggan dari sesuatu yang mengakibatkan tidak terpenuhinya hak-hak tersebut (Philipus M. Hadjon, 1986). Perlindungan hukum adalah tindakan atau upaya untuk melindungi masyarakat dari perbuatan sewenang-wenang oleh penguasa yang tidak sesuai dengan aturan hukum, untuk mewujudkan ketertiban dan ketentraman sehingga memungkinkan manusia untuk menikmati martabatnya sebagai manusia.

Muchsin menyatakan perlindungan hukum merupakan kegiatan untuk melindungi individu dengan menyerasikan hubungan nilai-nilai atau kaidah-kaidah yang menjelma dalam sikap dan tindakan dalam menciptakan adanya ketertiban dalam pergaulan hidup antar sesama manusia. Hal ini menegaskan perlindungan hukum merupakan suatu hal yang melindungi subjek-subjek hukum melalui peraturan perundang-undangan yang berlaku dan dipaksakan pelaksanaannya dengan suatu sanksi (Muchsin, 2001). Perlindungan hukum dapat dibedakan menjadi dua, yaitu: Perlindungan hukum preventif dan Perlindungan hukum represif.

Perlindungan yang diberikan oleh pemerintah dengan tujuan untuk mencegah sebelum terjadinya pelanggaran. Hal ini terdapat dalam peraturan perundang-undangan dengan maksud untuk mencegah suatu pelanggaran serta memberikan rambu-rambu atau batasan-batasan dalam melakukan sutu kewajiban.
Perlindungan hukum represif merupakan perlindungan akhir berupa sanksi seperti denda, penjara, dan hukuman tambahan yang diberikan apabila sudah terjadi sengketa atau telah dilakukan suatu pelanggaran. Menurut Philipus M. Hadjon, bahwa sarana perlindungan hukum ada dua macam, yaitu: (1) Pada perlindungan hukum preventif ini, subjek hukum diberikan kesempatan untuk mengajukan keberatan atau pendapatnya sebelum suatu keputusan pemerintah mendapat bentuk yang definitif. Tujuannya adalah mencegah terjadinya sengketa. Perlindungan hukum preventif sangat besar artinya bagi tindak pemerintahan yang didasarkan pada kebebasan bertindak karena dengan adanya perlindungan hukum yang preventif pemerintah terdorong untuk bersifat hati-hati dalam mengambil keputusan yang didasarkan pada diskresi. Di Indonesia, belum ada pengaturan khusus mengenai perlindungan hukum preventif. (2) Sarana perlindungan hukum represif

Perlindungan hukum yang represif bertujuan menyelesaikan sengketa. Penanganan perlindungan hukum oleh Pengadilan Umum dan Pengadilan Administrasi di Indonesia termasuk kategori perlindungan hukum ini. Prinsip perlindungan hukum terhadap tindakan pemerintah bertumpu dan bersumber dari konsep tentang pengakuan dan perlindungan terhadap hak-hak asasi manusia karena menurut sejarah dari barat, lahirnya konsepkonsep tentang pengakuan dan perlindungan terhadap hak-hak asasi manusia diarahkan kepada pembatasan-pembatasan dan peletakan kewajiban masyarakat dan pemerintah. Prinsip kedua yang mendasari perlindungan hukum terhadap tindak pemerintahan adalah prinsip negara hukum. Dikaitkan dengan pengakuan dan perlindungan terhadap hak-hak asasi manusia, pengakuan dan perlindungan terhadap hak-hak asasi manusia mendapat tempat utama dan dapat dikaitkan dengan tujuan dari negara hukum.

\section{Pengaturan Pendidikan dalam Undang-Undang Nomor 23 Tahun 2014 tentang Pemerintahan Daerah}

Sebagaimana diamanatkan oleh UndangUndang Dasar Negara Republik Indonesia Tahun 1945, terdapat Urusan Pemerintahan yang sepenuhnya menjadi kewenangan Pemerintah Pusat 
yang dikenal dengan istilah urusan pemerintahan absolut dan ada urusan pemerintahan konkuren. Urusan pemerintahan konkuren terdiri atas Urusan Pemerintahan Wajib dan Urusan Pemerintahan Pilihan yang dibagi antara Pemerintah Pusat, Daerah provinsi, dan Daerah kabupaten/kota. Urusan Pemerintahan Wajib dibagi dalam Urusan Pemerintahan Wajib yang terkait Pelayanan Dasar dan Urusan Pemerintahan Wajib yang tidak terkait Pelayanan Dasar. Untuk Urusan Pemerintahan Wajib yang terkait Pelayanan Dasar ditentukan Standar Pelayanan Minimal (SPM) untuk menjamin hak-hak konstitusional masyarakat.

Urusan Pemerintahan terdiri atas urusan pemerintahan absolut, urusan pemerintahan konkuren, dan urusan pemerintahan umum. Urusan pemerintahan absolut adalah Urusan Pemerintahan yang sepenuhnya menjadi kewenangan Pemerintah Pusat. Urusan pemerintahan konkuren adalah Urusan Pemerintahan yang dibagi antara Pemerintah Pusat dan Daerah provinsi dan Daerah kabupaten/kota. Urusan pemerintahan konkuren adalah Urusan Pemerintahan yang dibagi antara Pemerintah Pusat dan Daerah provinsi dan Daerah kabupaten/kota. Urusan pemerintahan umum adalah Urusan Pemerintahan yang menjadi kewenangan Presiden sebagai kepala pemerintahan.

Urusan pemerintahan konkuren yang diserahkan ke Daerah menjadi dasar pelaksanaan Otonomi Daerah. Urusan pemerintahan konkuren menjadi kewenangan Daerah terdiri atas Urusan Pemerintahan Wajib dan Urusan Pemerintahan Pilihan. Urusan Pemerintahan Wajib terdiri atas Urusan Pemerintahan yang berkaitan dengan Pelayanan Dasar dan Urusan Pemerintahan yang tidak berkaitan dengan Pelayanan Dasar. Urusan Pemerintahan Wajib yang berkaitan dengan Pelayanan Dasar adalah Urusan Pemerintahan Wajib yang sebagian substansinya merupakan Pelayanan Dasar.

Urusan Pemerintahan Wajib yang berkaitan dengan Pelayanan Dasar meliputi: pendidikan; kesehatan; pekerjaan umum dan penataan ruang; perumahan rakyat dan kawasan permukiman; ketenteraman, ketertiban umum, dan pelindungan masyarakat; dan sosial.

Urusan Pemerintahan Wajib yang tidak berkaitan dengan Pelayanan Dasar meliputi, tenaga kerja pemberdayaan perempuan dan pelindungan anak, pangan, pertanahan, lingkungan hidup, administrasi kependudukan dan pencatatan sipil, pemberdayaan masyarakat dan Desa, pengendalian penduduk dan keluarga berencana, perhubungan, komunikasi dan informatika, koperasi, usaha kecil, dan menengah, penanaman modal, kepemudaan dan olah raga, statistic, persandian, kebudayaan, perpustakaan, dan kearsipan. Otonomi daerah juga berkaitan dengan pengembangan pendidikan. Otonomi daerah di bidang pendidikan di satu sisi tidak bisa lepas dari gerakan global yaitu demokratisasi (Baharun, 2012). Demokrastiasasi pendidikan diharapkan dapat meningkatkan kualitas.

Urusan Pemerintahan Pilihan meliputi kelautan dan perikanan, pariwisata, pertanian; kehutanan; energi dan sumber daya mineral; perdagangan; perindustrian; dan transmigrasi. Pembagian urusan pemerintahan konkuren antara Pemerintah Pusat dan Daerah provinsi serta Daerah kabupaten/kota didasarkan pada prinsip akuntabilitas, efisiensi, dan eksternalitas, serta kepentingan strategis nasional.

Pembagian urusan pemerintahan konkuren antara Daerah provinsi dengan Daerah kabupaten/kota walaupun Urusan Pemerintahan sama, perbedaannya akan nampak dari skala atau ruang lingkup Urusan Pemerintahan tersebut. Walaupun Daerah provinsi dan Daerah kabupaten/kota mempunyai Urusan Pemerintahan masing-masing yang sifatnya tidak hierarki, namun tetap akan terdapat hubungan antara Pemerintah Pusat, Daerah provinsi dan Daerah kabupaten/kota dalam pelaksanaannya dengan mengacu kebijakan yang dibuat oleh Pemerintah Pusat.

Kebijakan pendidikan dalam UU Nomor 23 Tahun 2014 tentang Pemerintahan Daerah tidak lagi diserahkan kepada pemerintah daerah kabupaten/kota lagi semuanya. Urusan pendidikan dalam UU Nomor 23 Tahun 2014 tentang Pemerintahan Daerah dibagi dalam manajemen pendidikan, kurikulum, akreditasi, pendidik dan tenaga kependidikan, perizinan pendidikan, serta bahasa dan sastra. Urusan pendidikan tersebut oleh UU Nomor 23 Tahun 2014 tentang Pemerintahan Daerah. 
Perlindungan Hukum bagi Guru yang Dimutasi Setelah Diberlakukannya UU Nomor 23 Tahun 2014 tentang Pemerintahan Daereh Perlindungan yang sifatnya preventif. Perlindungan hukum menurut UU Nomor 23 Tahun 2014 tentang Pemerintahan Daerah. Mengingat kondisi geografis yang sangat luas, untuk efektivitas dan efisiensi pembinaan dan pengawasan atas penyelenggaraan Urusan Pemerintahan yang menjadi kewenangan Daerah kabupaten/kota, Presiden sebagai penanggung jawab akhir pemerintahan secara keseluruhan melimpahkan kewenangannya kepada gubernur untuk bertindak atas nama Pemerintah Pusat untuk melakukan pembinaan dan pengawasan kepada Daerah kabupaten/kota agar melaksanakan otonominya dalam koridor yang ditetapkan oleh Pemerintah Pusat. Untuk efektifitas pelaksanaan tugasnya selaku wakil Pemerintah Pusat, gubernur dibantu oleh perangkat gubernur sebagai Wakil Pemerintah Pusat. Oleh karena perannya sebagai Wakil Pemerintah Pusat, hubungan antara gubernur dan Pemerintah Daerah kabupaten/kota bersifat hierarkis. Penguasa adalah penting bahwa para penguasa yang muncul harus menajdi kelas pengrajin yang bersemangat publik dalam temperamen dan terampil dalam seni daerah pemerintahan, para wali harus ditempatkan dalam posisi dimana mereka penguasa mutlak, mereka seharusnya beberapa orang terpilih yang tahu apa yang terbaik bagi masyarakat (Suwarma, 2017: 220). Dalam melaksanakan pembinaan dan pengawasan terhadap penyelenggaraan Urusan Pemerintahan yang menjadi kewenangan Daerah kabupaten/kota dan Tugas Pembantuan oleh Daerah kabupaten/kota, Presiden dibantu oleh gubernur sebagai wakil Pemerintah Pusat. Dalam melaksanakan pembinaan dan pengawasan, gubernur sebagai wakil Pemerintah Pusat mempunyai tugas: (1) mengoordinasikan pembinaan dan pengawasan penyelenggaraan Tugas Pembantuan di Daerah kabupaten/kota; (2) melakukan monitoring, evaluasi, dan supervisi terhadap penyelenggaraan Pemerintahan Daerah kabupaten/kota yang ada di wilayahnya; (3) memberdayakan dan memfasilitasi Daerah kabupaten/kota di wilayahnya; (4) melakukan evaluasi terhadap rancangan Perda Kabupaten/Kota tentang RPJPD, RPJMD, APBD, perubahan APBD, pertanggungjawaban pelaksanaan APBD, tata ruang daerah, pajak daerah, dan retribusi daerah; (5) melakukan pengawasan terhadap Perda Kabupaten/Kota; dan (6) melaksanakan tugas lain sesuai dengan ketentuan peraturan perundang-undangan.

Dalam melaksanakan tugas pembinaan dan pengawasan, gubernur sebagai wakil Pemerintah Pusat mempunyai wewenang: (a) membatalkan Perda Kabupaten/Kota dan peraturan bupati/wali kota; (b) memberikan penghargaan atau sanksi kepada bupati/wali kota terkait dengan penyelenggaraan Pemerintahan Daerah; (c) menyelesaikan perselisihan dalam penyelenggaraan fungsi pemerintahan antar-Daerah kabupaten/kota dalam 1 (satu) Daerah provinsi; (d) memberikan persetujuan terhadap rancangan Perda Kabupaten/Kota tentang pembentukan dan susunan Perangkat Daerah kabupaten/kota; dan (e) melaksanakan wewenang lain sesuai dengan ketentuan peraturan perundang-undangan.

Perlindungan hukum yang diperoleh guru berdasarkan UU Nomor 23 Tahun 2014 tentang Pemerintahan Daerah adalah pembatalan surat yang memutasi diri dari gubernur. Sebagaimana dijelaskan SE Mendagri Nomor 120/5935/SJ tanggal 16 Oktober 2015 tentang Percepatan Pelaksanaan Pengalihan Urusan Berdasarkan Undang-Undang Nomor 23 Tahun 2014 tentang Pemerintahan Daerah, jika mutasi terjadi sebelum tanggal 2 Oktober 2016, hal tersebut tidak boleh dilakukan sehingga gubernur berwenang membatalkan.

Persoalan utamanya adalah terjadinya perbedaan penafsiran "beralih urusannya" bahwa beralih urusan itu bukan hanya urusan konkuren sebagaimana dinyatakan dengan tegas dalam Angka (1) SE Mendagri tersebut, melainkan ditafsirkan urusan pemerintahan yang meliputi 3 hal tersebut, yaitu absolut, konkuren, dan pemerintahan umum. Guru bisa dimutasikan karena tidak terjadi perpindahan urusan, dalam hal ini, dari urusan konkuren 
pindah ke urusan konkuren. Jika ditafsirkan demikian, bagaimana guru harus meminta perlindungan hukum? Salah satu jalan yang bisa ditempuh oleh guru adalah gugatan ke Pengadilan Tata Usaha Negara.

\section{Perlindungan yang sifatnya represif}

Guru sebagai pegawai negeri sipil dapat menjadi subjek sengketa tata usaha negara jika guru tersebut mengalami mutasi/perpindahan yang dianggapnya tidak sesuai dengan asas umum pemerintahan yang baik atau asas keadilan. Surat mutasi atau perpindahannya itu yang merupakan objek sengketa tata usaha negara. Surat mutasi tersebut dapat dianggap sebagai keputusan tata usaha negara.

Keputusan tata usaha negara adalah suatu penetapan tertulis yang dikeluarkan oleh badan atau pejabat tata usaha negara yang berisi tindakan hukum tata usaha negara yang berdasarkan peraturan perundang-undangan yang berlaku, yang bersifat konkret, individual, dan final, yang menimbulkan akibat hukum bagi seseorang atau badan hukum perdata. Tidak termasuk dalam pengertian Keputusan Tata Usaha Negara menurut Undang-Undang ini: (a) Keputusan Tata Usaha Negara yang merupakan perbuatan hukum perdata; (b) Keputusan Tata Usaha Negara yang merupakan pengaturan yang bersifat umum; (c) Keputusan Tata Usaha Negara yang masih memerlukan persetujuan; (d) Keputusan Tata Usaha Negara yang dikeluarkan berdasarkan ketentuan Kitab Undang-Undang Hukum Pidana dan Kitab Undang-Undang Hukum Acara Pidana atau peraturan erundangundangan lain yang bersifat hukum pidana; (e) Keputusan Tata Usaha Negara yang dikeluarkan atas dasar hasil pemeriksaan badan peradilan berdasarkan ketentuan peraturan perundangundangan yang berlaku; (f) Keputusan Tata Usaha Negara mengenai tata usaha Tentara Nasional Indonesia; (g) Keputusan Komisi Pemilihan Umum baik di pusat maupun di daerah mengenai hasil pemilihan umum.

Undang-Undang Nomor 51 Tahun 2009 jo Undang-Undang Nomor 9 Tahun 2004 jo Undang-Undang Nomor 5 Tahun 1986 dalam salah satu pasalnya menyatakan orang atau badan hukum perdata yang merasa kepentingannya dirugikan oleh suatu Keputusan Tata Usaha Negara dapat mengajukan gugatan tertulis kepada pengadilan yang berwenang yang berisi tuntutan agar Keputusan Tata Usaha Negara yang disengketakan itu dinyatakan batal atau tidak sah, dengan atau tanpa disertai tuntutan ganti rugi dan/atau direhabilitasi (Pasal 53 Ayat (1) Undang-Undang Nomor 51 Tahun 2009 jo Undang-Undang Nomor 9 Tahun 2004 jo Undang-Undang Nomor 5 Tahun 1986).

Alasan-alasan yang dapat digunakan dalam gugatan adalah: (a) Keputusan Tata Usaha Negara yang digugat itu bertentangan dengan peraturan perundang-undangan yang berlaku; (b) Keputusan Tata Usaha Negara yang digugat itu bertentangan dengan asas-asas umum pemerintahan yang baik.

Jika guru merasa dirugikan, guru bisa mengajukan gugatan dengan alasan gugatan sebagaimana sudah disebutkan di atas. Jika berkaitan dengan mutasi, dalam hal ini, pelaksanaan SE Mendagri Nomor 120/5935/SJ tanggal 16 Oktober 2015 tentang Percepatan Pelaksanaan Pengalihan Urusan Berdasarkan Undang-Undang Nomor 23 Tahun 2014 tentang Pemerintahan Daerah, guru bisa mengajukan gugatan dengan alasan bertentangan dengan peraturan perundang-undangan yang berlaku. Jika guru dipindah tanpa ada alasan yang jelas, dia bisa menggugat dengan alasan keputusan tata usaha negara yang digugat itu bertentangan dengan asas-asas umum pemerintahan yang baik

Pengadilan Tata Usaha dapat memberikan perlindungan hukum melalui putusan persidangan. Perlindungan tersebut di antaranya:

Salinan putusan pengadilan yang telah memperoleh kekuatan hukum tetap, dikirimkan kepada para pihak dengan surat tercatat oleh panitera pengadilan setempat atas perintah ketua pengadilan yang mengadilinya dalam tingkat pertama selambat-lambatnya dalam waktu 14 (empat belas) hari kerja. Artinya, pihak yang tergugat juga menerima putusan tersebut agar dilaksanakan.

Apabila setelah 60 (enam puluh) hari kerja putusan pengadilan yang telah memperoleh 
kekuatan hukum tetap diterima tergugat tidak melaksanakan kewajibannya sebagaimana dimaksud dalam Pasal 97 ayat (9) huruf a, keputusan tata usaha negara yang disengketakan itu tidak mempunyai kekuatan hukum lagi. Pasal 97 Ayat (9) huruf a Undang-Undang Nomor 51 Tahun 2009 jo Undang-Undang Nomor 9 Tahun 2004 jo Undang-Undang Nomor 5 Tahun 1986 menyatakan Kewajiban sebagaimana dimaksud dalam ayat (8) berupa : a. pencabutan Keputusan Tata Usaha Negara yang bersangkutan.

Dalam hal tergugat ditetapkan harus melaksanakan kewajiban sebagaimana dimaksud dalam Pasal 97 ayat (9) huruf b dan huruf c, dan kemudian setelah 90 (sembilan puluh) hari kerja ternyata kewajiban tersebut tidak dilaksanakan, maka penggugat mengajukan permohonan kepada ketua, agar pengadilan memerintahkan tergugat melaksanakan putusan pengadilan tersebut. Pasal 97 ayat (9) huruf b dan huruf c Undang-Undang Nomor 51 Tahun 2009 jo Undang-Undang Nomor 9 Tahun 2004 jo Undang-Undang Nomor 5 Tahun 1986 menyatakan b. pencabutan Keputusan Tata Usaha Negara yang bersangkutan dan menerbitkan Keputusan Tata Usaha Negara yang baru; atau c. penerbitan Keputusan Tata Usaha Negara dalam hal gugatan didasarkan pada Pasal 3.

Pasal 3 Undang-Undang Nomor 51 Tahun 2009 jo Undang-Undang Nomor 9 Tahun 2004 jo Undang-Undang Nomor 5 Tahun 1986 menyatakan Ayat (1) Apabila Badan atau Pejabat Tata Usaha Negara tidak mengeluarkan keputusan, sedangkan hal itu menjadi kewajibannya, maka hal tersebut disamakan dengan Keputusan Tata Usaha Negara, Ayat (2) Jika suatu Badan atau Pejabat Tata Usaha Negara tidak mengeluarkan keputusan yang dimohon, sedangkan jangka waktu sebagaimana ditentukan data peraturan perundang-undangan dimaksud telah lewat, maka Badan atau Pejabat Tata Usaha Negara tersebut dianggap telah menolak mengeluarkan keputusan yang dimaksud, dan Ayat (3) Dalam hal peraturan perundang-undangan yang bersangkutan tidak menentukan jangka waktu sebagaimana dimaksud dalam ayat (2), maka setelah lewat jangka waktu empat bulan sejak diterimnya permohonan, Badan atau Pejabat Tata Usaha Negara yang bersangkutan dianggap telah mengeluarkan keputusan penolakan.

Dalam hal tergugat tidak bersedia melaksanakan putusan pengadilan yang telah memperoleh kekuatan hukum tetap, terhadap pejabat yang bersangkutan dikenakan upaya paksa berupa pembayaran sejumlah uang paksa dan/atau sanksi administratif.

Pejabat yang tidak melaksanakan putusan pengadilan diumumkan pada media massa cetak setempat oleh panitera sejak 90 (sembilan puluh) hari kerja. ) Jika suatu Badan atau Pejabat Tata Usaha Negara tidak mengeluarkan keputusan yang dimohon, sedangkan jangka waktu sebagaimana ditentukan data peraturan perundang-undangan dimaksud telah lewat, maka Badan atau Pejabat Tata Usaha Negara tersebut dianggap telah menolak mengeluarkan keputusan yang dimaksud.

Di samping diumumkan pada media massa cetak setempat, ketua pengadilan harus mengajukan hal ini kepada Presiden sebagai pemegang kekuasaan pemerintah tertinggi untuk memerintahkan pejabat tersebut melaksanakan putusan pengadilan, dan kepada lembaga perwakilan rakyat untuk menjalankan fungsi pengawasan.

Perlindungan hukum membutuhkan satu hal yang tidak kalah pentingnya, yaitu penegakan hukum. Penegakan hukum merupakan suatu usaha untuk mewujudkan ideide keadilan, kepastian hukum, dan kemanfaatan sosial menjadi kenyataan. Proses bekerjanya aparatur penegak hukum itu, terdapat tiga elemen penting yang memengaruhi, yaitu: (i) institusi penegak hukum beserta berbagai perangkat sarana dan prasarana pendukung dan mekanisme kerja kelembagaannya; (ii) budaya kerja yang terkait dengan aparatnya, termasuk mengenai kesejahteraan aparatnya, dan (iii) perangkat peraturan yang mendukung baik kinerja kelembagaannya maupun yang mengatur materi hukum yang dijadikan standar kerja, baik hukum materielnya maupun hukum acaranya. Upaya penegakan hukum secara sistemik haruslah memperhatikan ketiga aspek itu secara 
simultan, sehingga proses penegakan hukum dan keadilan itu sendiri secara internal dapat diwujudkan secara nyata.

\section{SIMPULAN}

Berdasarkan hasil dan pembahasan diaatas maka dapat disimpulkan bahwa mutasi guru yang dilaksanakan dalam rangka pengalihan urusan konkuren, baik secara internal kabupaten/kota maupun provinsi, harus dilakukan setelah bulan Oktober 2016. Jika dilakukan sebelum tanggal tersebut harus segera dikembalikan ke posisi semula.

Perlindungan hukum terhadap guru bisa dilakukan secara preventif dan represif. Secara preventif, bisa melalui kewenangan gubernur sebagai wakil pemerintah untuk membatalkan keputusan tersebut dan secara represif, guru bisa mengajukan tuntutan kepada pengadilan Tata Usaha Negara untuk membatalkan surat keputusan mutasinya.

\section{DAFTAR PUSTAKA}

Baharun, H. (2012). Desentralisasi dan implikasinya terhadap pengembangan sistem pendidikan Islam. Junal At-Tajdid , 241-254.

Muchsin. 2001. Hukum Administrasi Negara. Yogyakarta: CV Liberty

Philipus M. Hadjon. 1986. Perlindungan Hukum di Indonesia. Jakarta: CV Ghalia Indonesia

Satjipto Rahardjo. 2001. Ilmu Hukum. Bandung: CV Citra Aditya Bakti

SE Mendagri Nomor 120/5935/SJ tanggal 16 Oktober 2015 tentang Percepatan Pelaksanaan Pengalihan Urusan Berdasarkan UndangUndang Nomor 23 Tahun 2014 tentang Pemerintahan Daerah

Suwarma Al Muchtar, 2017. Filsafat Politik. Bandung: CV. Gelar Pustaka Mandiri

Undang-Undang Nomor 51 Tahun 2009 jo UndangUndang Nomor 9 Tahun 2004 jo UndangUndang Nomor 5 Tahun 1986 tentang Pengadilan Tata Usaha Negara

Undang-Undang Nomor 20 Tahun 2003 tentang Sistem Pendidikan Nasional

Undang-Undang Nomor 23 Tahun 2014 tentang Pemerintahan Daera. 